\title{
Morphometric traits of shells determine external attack and internal utilization marks in the Roman snail in eastern Germany
}

\author{
Claudia Tluste $^{1}$, Udo Bröring ${ }^{1}$, Tomáš Němec ${ }^{2}$, and Klaus Birkhofer ${ }^{1}$ \\ ${ }^{1}$ Department of Ecology, Brandenburg University of Technology, Konrad-Wachsmann-Allee 6, \\ 03046 Cottbus, Germany \\ ${ }^{2}$ Department of Botany and Zoology, Masaryk University, Kotlářská 2, 61137 Brno, Czech Republic \\ Correspondence: Claudia Tluste (claudia.fuessel@yahoo.de)
}

Received: 11 February 2020 - Revised: 9 June 2020 - Accepted: 29 June 2020 - Published: 10 August 2020

\begin{abstract}
Overexploitation, habitat destruction and a changing climate threaten populations of the Roman snail (Helix pomatia Linnaeus, 1758), which has led to a high protection status in Germany. Vertebrate and invertebrate predators, including parasites and facultative parasitoids, further cause pressure on populations. Given the conservation concern for $\mathrm{H}$. pomatia and its rarity in the study region (Cottbus, Germany), we studied how predators and facultative parasitoids utilize $\mathrm{H}$. pomatia shells with a focus on non-invasive field methods. As previous studies indicated that shell size may affect prey selection by predators, morphometric traits were measured in eight subpopulations. We identified the total number and percentage of $H$. pomatia shells that showed external attack marks by predators and internal utilization marks by Diptera pupae and related those utilization patterns to the morphometric traits of shells. A large proportion of the shells in local subpopulations showed signs of external attack and internal utilization, and both utilization forms were positively correlated. External attacks by predators were more frequent in larger shells and internal utilization by Diptera was more common in shells with higher body density. These results suggest a considerable pressure by predators and potential facultative parasitoids on $H$. pomatia populations in the study area. Future research should focus on the relationship between snails from the family Helicidae and flies from the genus Discomyza. Conservation programmes should consider abiotic habitat conditions together with potential trophic interactions to maximize the success of conservation strategies.
\end{abstract}

\section{Introduction}

The Roman snail (Helix pomatia Linnaeus, 1758) is of considerable commercial interest as human food (also called "edible snail"; Bloszyk et al., 2010; Gheoca, 2013) and in medical research (Dwek et al., 2001). Exploitation by humans is a potential cause for population declines (Welch and Pollard, 1975; Andreev, 2006), especially as the species has a relatively slow reproduction and maturation rate (Ligaszewski et al., 2014) and long dormancy periods (Lind, 1989). Nevertheless habitat destruction (Andreev, 2006) and a changing climate (Nicolai and Ansart, 2017) may threaten $H$. pomatia populations in the future as well, particularly in areas with unfavourable soil conditions. Those conser- vation concerns resulted in the development of breeding programmes to protect the species (Hardouin, 1995; Ligaszewski et al., 2014). National and EU-level regulations address overexploitation by creating different protection categories (Bouchet et al., 1999; Ligaszewski et al., 2016). National regulations protect $H$. pomatia in Germany (Bundesartenschutzverordnung (BArtSchV) Paragraph 1 Satz 1) and control the collection of snails, but they do not implement specific conservation programmes. The study area, in the Federal State of Brandenburg has a continental, dry climate with a limited presence of calcareous soils which both contribute to the rarity of the species and through this increase its conservation value. A citizen science project coordinated by the Nature and Biodiversity Conservation Union focuses 
on the identification of remaining habitats of $H$. pomatia and highlights the public awareness for the conservation of this species in the study region (NABU, 2019).

In addition to human exploitation, habitat management and climatic fluctuations, pressure from natural enemies may further affect populations of $H$. pomatia. Birds (e.g. Coracias garrulus Linnaeus (European roller) and Phasianus colchicus Linnaeus (pheasant)), rodents (e.g. Apodemus sylvaticus (Linnaeus) (wood mouse) or Rattus rattus (Linnaeus) (black rat)), reptiles (e.g. Anguis fragilis Linnaeus, 1758 (slow worm)) and ground beetles (e.g. Cychrus species) feed on H. pomatia (Coupland and Barker, 2004). Cychrus species even have morphological adaptations to their mouth parts to allow them to attack and consume snails (Digweed, 1993), but other, more opportunistic predaceous ground beetle species also attack terrestrial snails (Larochelle, 1990). Several Diptera species (e.g. Fannia canicularis (Linnaeus), Sarcophaga (Myorhina) nigrivantris, Chaetopleurophora bohemanni or Spiniphora bergenstammi) may act as facultative parasitoids of $H$. pomatia (Barker et al., 2004). For other Diptera species, information is less well known or conflicting. For example, Discomyza species, like D. incurva, breed in dead snails (Ferrar, 1987; Zatwarnicki and Mathis, 2007) and have been considered as parasites of $H$. pomatia for a long time (von Bergenstamm, 1864). Previous studies from Europe describe the occurrence of $D$. incurva in snail shells as rare or did not find this species in shells (Beaver, 1977; Buck et al., 2006).

Very little is known about population-level effects of predation on terrestrial snails (Millar and Waite, 1999), but even less is known about selection of prey or host snails by predators or parasitoids (Vermeij, 1995). Natural enemies of terrestrial snails often leave marks on the shell, either through external attack marks damaging the shell or internal utilization marks by larvae of pupae. Only two previous studies have used these marks to contribute to a better understanding of predation on terrestrial snails: Millar and Waite (2004) recorded patterns of shell damage in an English woodland and Němec and Horsák (2019) recently compared the identity of predator groups causing marks on the shells of the steppe snail Granaria frumentum (Draparnaud, 1801). Predation at the population level affects morphometric traits of shells (e.g. shell size; Goodfriend, 1986), and larger shells may even suggest a selective advantage against future predation (Liew and Schilthuizen, 2014). Shell size also affects predation, as for example smaller individuals of Cepaea nemoralis (Linnaeus, 1758) are more frequently attacked by beetles than larger individuals (Oosterhoff, 1977). Birds, for example song thrushes, showed preferences for larger shell sizes in the same species, but prey choice also depended on the different morphs in this snail species (reviewed in Goodfriend, 1986). Simultaneously considering external attack and internal utilization marks on snail shells together with morphometric shell traits will therefore contribute to a better understanding of attack and utilization patterns in $H$. pomatia populations.

Given the conservation concern for $H$. pomatia and its rarity in the study region, this field study focused on an improved understanding of how predators and facultative parasitoids utilize $H$. pomatia, with a focus on non-invasive field methods. We identified the number and percentage of $H$. pomatia shells that showed external attack marks by predators and internal utilization marks by Diptera pupae. To understand drivers of attack and utilization patterns, we measured morphometric traits of shells and related them to the observed proportion of marks in local subpopulations. We hypothesize that larger snail shells are more vulnerable to external attacks of predators due to a higher visibility but that the proportion of internal utilization marks by Diptera pupae is independent of morphometric traits.

\section{Material and methods}

\subsection{Study area and snail sampling}

The study area "Sachsendorfer Wiesen" is part of an approximately 350 ha large nature conservation area in Cottbus, Germany (Wollmann, 2002). After previous intensive agricultural use, the area has been managed as an amenity grassland since 1991. The single management practice is mowing, and the cutting frequency is once or twice a year. The vegetation in the area is dominated by Urtica dioica L. (common nettle), Aegopodium podagraria L. (ground elder) and Chelidonium majus L. (greater celandine).

The municipality of Cottbus gave permission to perform this research, under the conditions that no individuals of $H$. pomatia will be harmed and that areas that have been designated for the protection of the bird species Crex crex (Linnaeus, 1758) (corn crake) will not be entered.

We selected eight subpopulations of $H$. pomatia with a minimum distance of $30 \mathrm{~m}$ and physical barriers such as by railway tracks or buildings between them. Prior to the sampling of shells, the whole study area was carefully surveyed for the presence of $H$. pomatia individuals and subpopulation habitats were selected based on their isolation from nearby habitat patches. Between 28 September 2016 and 30 November 2017, the same researcher sampled 642 empty $H$. pomatia shells (range of shells per subpopulation 34-166; Table 1) for examination of external attack marks by predators or internal utilization marks by Diptera pupae. Visual search for empty shells is a non-destructive sampling technique, which is a key priority for studies of protected species. This approach across the subpopulation area was optimized for the collection of a high number of empty shells across the subpopulation area. However, estimates of morphometric traits may be biased towards larger, more conspicuous shells, and attack and utilization marks may result from interactions after the snail already died. To estimate subpopulation densities, we visually counted all living individuals in spring 2017 
and spring 2018 within an area of $9 \mathrm{~m}^{2}$ at three locations in each subpopulation. This approach was optimized for a standardized sampling of subregions in each subpopulation to derive reliable estimates of population sizes of living snails. Live individuals of the protected species $H$. pomatia were not sampled or killed during this study.

\subsection{Utilization marks}

Out of the total 642 shells that were sampled for external attack marks, a random subsample of 353 shells was opened and checked for internal utilization marks by Diptera pupae. This was done in the laboratory, where we used needle-nose pliers to open shells from the aperture around the columella up to the apex. All marks indicating attacks on the outside of the shell were recorded in the category "external attack" (Fig. 1a). Note that these marks are not equivalent to predation records, as the cause of mortality remains unknown and as marks could result from post-mortem attacks. External damage to shells by larger mammals is very unlikely, as the area is not visited by wild boars and as visits from other larger mammals are extremely rare due to the close proximity to human infrastructure and settlements. Only shells with marks indicating the presence of Diptera pupae (preserved pupae or black marks on the inside of the shell indicating attachment points of pupae) were considered for the category internal utilization mark (Fig. $1 \mathrm{~b}$ and c). Discomyza incurva (Fallén, 1823), as a common species found in shells in this study, have larvae that are known to feed on decaying $H$. pomatia (von Bergenstamm, 1864; Sequy, 1934). It is unknown whether this species attacks living snails or primarily deposits eggs on snail carcasses (Kofler and Mildner, 2004), and internal marks cannot be differentiated between predation or scavenging events.

\subsection{Morphometric traits and soil pH}

The following morphometric traits were recorded from all subpopulations. The average mass of snails with shell was calculated on-site in each subpopulation by weighting living snails with a CS digital scale in April 2017 after hibernation. This was done per subpopulation for a minimum of 30 randomly selected snails per subpopulation to result in an average total mass of snails per subpopulation (hereafter 149 "mass total"). Between autumn 2016 and spring 2017 a minimum of 30 empty shells were collected in each subpopulation and weighed resulting in the average total mass (in $\mathrm{g}$ ) of shells per subpopulation (hereafter "mass shell"). The average

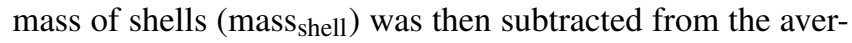
age mass of snails in each subpopulation (mass total $_{\text {) }}$ ) to provide an estimate of the mass of snail bodies without shells per subpopulation (hereafter "mass body"; Sepúlveda et al., 2012). In all subpopulations we measured 30 to 100 shells for shell height and width (in $\mathrm{mm}$ ) with a sliding calliper. Shell volume (hereafter "volume shell") was calculated for these shells by filling empty shells with sand and by then measuring the volume of sand per shell. Body density was mostly measured among aquatic gastropods in order to determine vulnerability regarding earthquakes or predators (Baums et al., 2003; Seike et al., 2019; Steward and McHenry, 2010), but this has not been addressed in terrestrial snails. Due to state laws considering the protection of $H$. pomatia, we needed to use a non-destructive method to calculate the quotient of the average body mass without shell (mass body) and the average volume of shells (volume shell $_{\text {) }}$ in each subpopulation.

To measure local soil $\mathrm{pH}, 76$ soil samples were taken from the upper $10 \mathrm{~cm}$ across the subpopulations. Depending on the area size for each subpopulation two to six soil samples were taken and the average soil $\mathrm{pH}$ was calculated for each area. Soil $\mathrm{pH}$ was measured using the Microprocessor-Präzisions-pH/mV-Meter pH 539 (Wissenschaftliche-Technische-Werkstätten $\mathrm{GmbH}$ ) and $0.01 \mathrm{M} \mathrm{CaCl}_{2}$. The soil sample was taken from the upper $10 \mathrm{~cm}$ as Helix pomatia is primarily in contact with this soil layer.

\subsection{Statistical analyses}

Regression analyses were performed with distance-based linear models (DistLMs), an approach which can use nonEuclidean resemblance measures and derives $p$ values from permutations (Legendre and Anderson, 1999; McArdle and Anderson, 2001). This approach has the advantages of allowing for internal standardization if predictor variables are not measured on the same scale (e.g. different morphometric traits like height in $\mathrm{mm}$ and mass in $\mathrm{g}$ ) and relaxes the assumption that errors have to be normally distributed (Anderson et al., 2008). To test for the effect of soil pH, the percentage of internal utilization or external attack marks and the number of pupae on subpopulation size, we independently related these four predictors to the local estimate of snail density with DistLM. To find the best model predicting the variation in all four considered morphometric traits, we related soil $\mathrm{pH}$, the percentage of internal utilization or external marks, and the number of pupae per shell as predictor variables to a resemblance matrix based on a multivariate dataset including the width $(\mathrm{mm})$, height $(\mathrm{mm})$, mass with $(\mathrm{g})$ and without shell $(\mathrm{g})$, and body density ratio in a single multiple multivariate regression model. We used Gower distances to generate a resemblance matrix of snail subpopulations to internally standardize for the different measurement scales of morphometric traits. The best model in this multiple, multivariate regression approach was selected based on data on from subpopulations $(N=8)$ and the AICc (version of Akaike information criterion with correction for small sample sizes). criteria for small sample sizes from all models with all possible predictor combinations. Models within $2 \Delta$ AICc units of the best model are considered in the results section. All $p$ values were based on 9999 permutations. Correlation analyses were performed using Pearson correlations. 
Table 1. The estimated subpopulation size, total number of shells examined (i.e. number of shells examined for external attack marks), percentage of shells with external attack marks, subset of shells examined for internal utilization marks, and percentage of shells with internal utilization marks. The final column shows the mean number of pupae observed per shell with internal utilization marks \pm standard error of the mean.

\begin{tabular}{|c|c|c|c|c|c|c|}
\hline Subpopulation & $\begin{array}{r}\text { Subpopulation } \\
\text { size }\end{array}$ & $\begin{array}{r}\text { No. shells } \\
\text { external }\end{array}$ & $\%$ external & $\begin{array}{r}\text { No. shells } \\
\text { internal }\end{array}$ & $\%$ internal & $\begin{array}{r}\text { Mean pupae } \\
\text { per shell }\end{array}$ \\
\hline 1 & 2736 & 63 & 66.7 & 34 & 64.7 & $16.5 \pm 4.6$ \\
\hline 2 & 2025 & 166 & 28.3 & 79 & 34.3 & $23.1 \pm 6.7$ \\
\hline 3 & 2793 & 144 & 14.6 & 77 & 48.6 & $25.1 \pm 5.9$ \\
\hline 4 & 163 & 51 & 41.2 & 30 & 56.7 & $21.2 \pm 4.8$ \\
\hline 5 & 1695 & 34 & 15.7 & 33 & 39.4 & $13.4 \pm 3.4$ \\
\hline 6 & 1553 & 107 & 31.8 & 35 & 48.6 & $11.3 \pm 2.9$ \\
\hline 7 & 268 & 35 & 48.6 & 34 & 50.0 & $16.4 \pm 3.3$ \\
\hline 8 & 2228 & 42 & 47.6 & 31 & 48.4 & $6.4 \pm 2.0$ \\
\hline
\end{tabular}
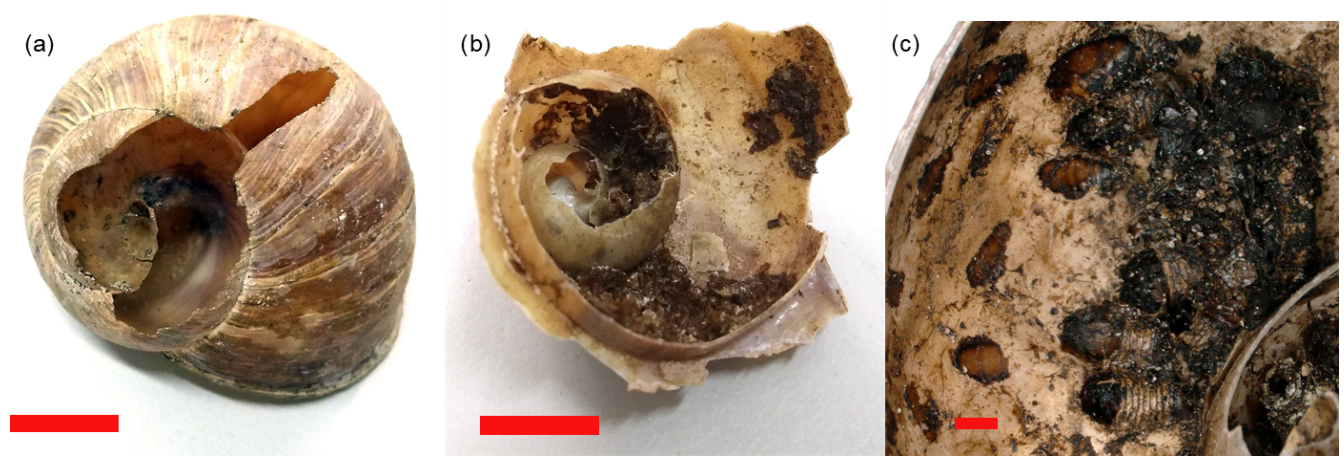

Figure 1. Helix pomatia shells with (a) external attack marks (bird attack), (b) internal utilization marks from Diptera pupae and (c) details of internal utilization marks with Diptera pupae. The scale bar shows $1 \mathrm{~cm}$ in (a) and (b) and $1 \mathrm{~mm}$ in (c).

Principle coordinates ordination (PCO) illustrates the relationships between morphometric traits and predictors in an unconstrained ordination. All statistical analyses were performed with Primer v7.0 and the PERMANOVA add-on.

\section{Results}

The average estimated density of snails across the subpopulations was $0.4 \pm 0.1$ (mean $\pm \mathrm{SD}$ ) individuals per square metre. Out of 642 shells of $H$. pomatia analysed for external attack marks, 207 (32\%) showed signs of external attacks (Table 1). Out of 353 shells analysed for marks of internal utilization by Diptera pupae, 159 (45\%) showed such signs.

The percentage of shells with external attack and internal utilization marks correlated significantly across subpopulations (Fig. 2a, $R=0.79 ; p=0.020$ ). The percentage of internal utilization marks further significantly correlated to the local soil $\mathrm{pH}$ across subpopulations (Fig. 2b, $R=-0.74$; $p=0.036)$. Other correlations between soil $\mathrm{pH}$, percentage of internal utilization and external attack marks, and average number of pupae per shell were not significant $(p>0.05)$.
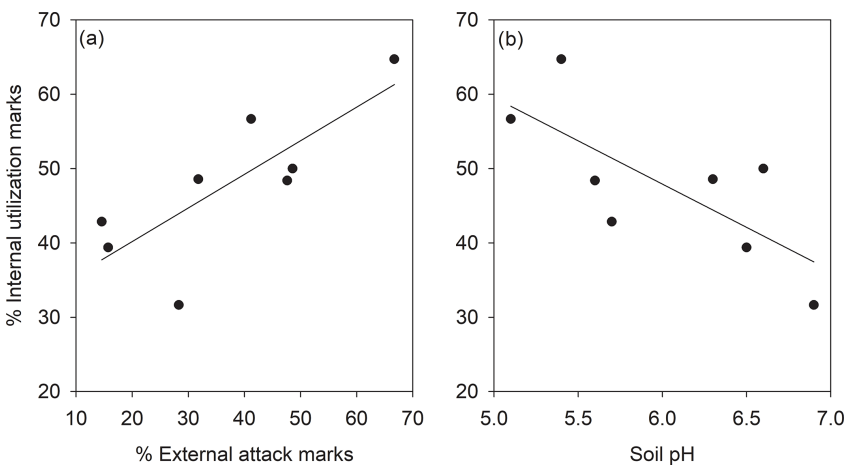

Figure 2. Relationship between internal utilization marks and (a) external attack marks and (b) soil $\mathrm{pH}$ in shells of Helix pomatia in the studied subpopulations $(N=8)$. Note that a single shell could show external attack and internal utilization marks.

The correlation of local density of snails per subpopulation was not significant to soil $\mathrm{pH}\left(R^{2}=0.39 ; p=0.108\right)$ or the percentage of internal $\left(R^{2}=0.04 ; p=0.410\right)$, external attack marks $\left(R^{2}=0.04 ; p=0.637\right)$ nor to the average number of pupae per attacked shell $\left(R^{2}=0.06 ; p=0.555\right)$. 


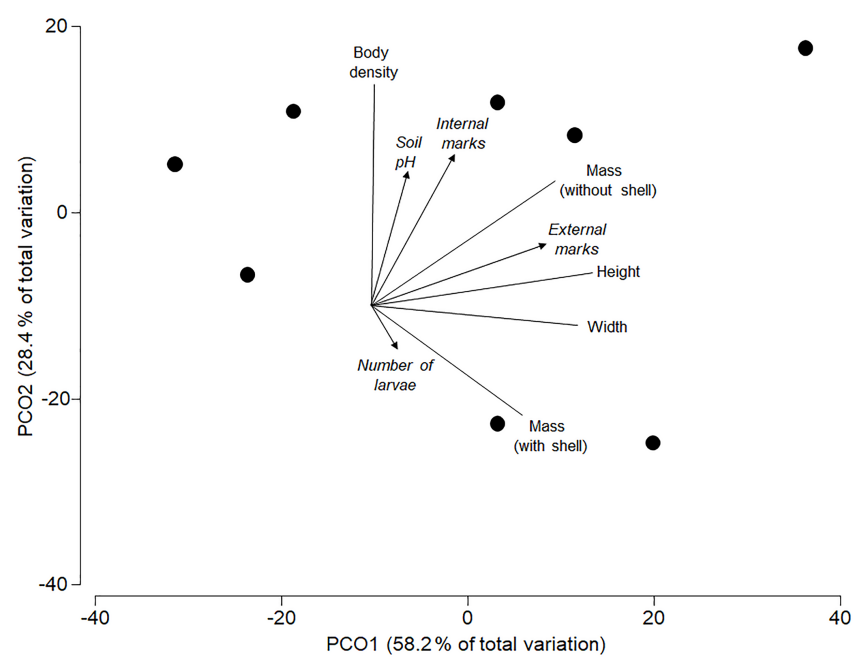

Figure 3. Principle coordinates ordination based on a resemblance matrix (Gower distances) from morphometric traits (shell height and width in millimetres, shell mass in grams, mass without shell in grams and body density in mass : volume ratio) in the studied subpopulations. Vectors for morphometric traits (without arrow) and predictors (with arrow: soil $\mathrm{pH}, \%$ internal utilization and external attack marks) were superimposed based on Pearson correlations with axis scores of the individual subpopulations.

In total, $49 \%$ of all analysed shells contained pupae and the average number of pupae per shell was $18.0 \pm 1.9$ (Table 1).

The best model to predict the variation in the analysed morphometric traits included the percentage of external attack marks as single significant predictor $(\mathrm{AICc}=$ 56.5; $R^{2}=0.35 ; p=0.039$ ), with one alternative model within $2 \triangle \mathrm{AICc}$ units (internal utilization marks only: AICc $\left.=58.07 ; R^{2}=0.21 ; p=0.219\right)$. Both soil pH $\left(R^{2}=0.06\right.$; $p=0.794)$ and the average number of pupae per shell $\left(R^{2}=\right.$ $0.03 ; p=0.911$ ) did not significantly affect the morphometric traits of shells. The ordination shows that most of the overall variation in all morphometric traits was explained by the individual variation in size (height and mass in Fig. 3) of shells (axis $1=58.2 \%$ ) and body density (axis $2=28.4 \%$ ). Larger shells had more external attack marks, and shells with higher body density had more internal utilization marks (Fig. 3).

Among the vertebrate predators in the study area, Turdus philomelos, Turdus merula Linnaeus, 1758 and Pica pica (Linnaeus, 1758) were most frequently observed. Arvicolinae and Natrix natrix (Linnaeus, 1758) were also present, but restricted to certain areas.

\section{Discussion}

A large proportion of the shells in local subpopulations showed signs of external attack (207 of 642 shells) and internal utilization (159 of 353 shells), and both utilization forms were positively correlated. Larger shells were more prone to external attack, and a higher body density resulted in more frequent internal utilization by Diptera. These results suggest a considerable pressure on $H$. pomatia by predators and potential facultative parasitoids in the study area.

Previous studies suggest that terrestrial snails are often not an important component of vertebrate diets and more related to certain periods (Goodhart, 1958; Davies and Snow, 1965; Gruar et al., 2003). Amongst the potential vertebrate predators, we observed T. philomelos, Turdus merula Linnaeus, 1758 and Pica pica (Linnaeus, 1758) to attack individuals of $H$. pomatia in the study area. Turdus philomelos may be a major predator of invertebrates in the study area, but snails account for less than $20 \%$ of the diet in this species, while other bird species incorporate even lower numbers of snails into their diet $(\leq 5 \%$; Krištin, 1992). Previous research showed that external predators prefer snails with bigger shells due to the investment of energy in handling and breaking snails (Zach, 1978; Rosin et al., 2011; Brodersen et al., 2002; Allen, 2004). Furthermore, most snails are nocturnal and hide during the day (South, 1992) and larger shells may be more conspicuous during daytime. This positive relationship between shell size and external attack rates on the shell may be most important for visual predators (e.g. birds), as smaller less visually oriented predators may rather prefer snail prey with smaller shells (e.g. Oosterhoff, 1977). The present study shows that subpopulations with larger shells have higher proportions of external attack marks than subpopulations with smaller shell size. High predation pressure can affect population dynamics in terrestrial snail species but does not necessarily lead to a decline in population size (Allen, 2004). Invertebrate species that attack snails from the outside may have different preferences. Several beetle species incorporate gastropods into their diet (Symondson, 2004) but prefer smaller and injured snails due to attraction by emitted mucus (Mead, 1961; Wheater, 1987; Digweed, 1993).

Regarding internal utilization, a large proportion of shells showed internal utilization marks from Diptera pupae (mainly genus Discomyza). In this study, we observed a large number of pupae (up to 128) per shell and $45 \%$ of all analysed shells showed signs of utilization by Discomyza pupae. Discomyza incurva was previously considered as rare or recorded in low numbers from snail shells (Drake, 2006; Hofer and Waitzbauer, 2000), an observation we could not confirm in this study. Buck et al. (2006) stated that Discomyza flies only have a limited impact on snail populations. Potential body density showed the strongest correlation with percentages of internal utilization marks per subpopulation, and a high body density may result in higher oviposition rates by female flies. A higher nutritional value in snails with higher body density could explain the observed relationship. Other studies already confirmed that female flies of the family Phoridae prefer protein-rich food (Coupland and Barker, 2004) and that the fecundity of female flies in the family Sciomyzidae depends on the quality of the food 
(Beaver, 1973; Knutson and Vala, 2002). However, it remains unknown to what extent Discomyza incurva attacks living snails or primarily feeds on snail carcasses. Future research in this area could focus on live samples of Helix pomatia and Discomyza incurva to study interactions between these species in the laboratory. Field observations should address the timing of attacks and the state of the snail/shell at times of attack by the fly.

Larvae from different Diptera species have different $\mathrm{pH}$ optima (Grunewald, 1976; Uutala, 1987; Arimoro et al., 2007). Manipulation of the $\mathrm{pH}$ value of food attractants for example considerably altered the number of attracted female fruit flies (Bateman and Morton, 1981; Epsky et al., 1993; Heath et al., 1994; Duyck et al., 2004). Regarding the observed positive relationship between soil $\mathrm{pH}$ and the percentage of internal utilization marks in this study, soil $\mathrm{pH}$ values may have indirectly affected the number of ovipositing female Diptera. Snails consume soil (Elmslie, 1998; Mensink and Henry, 2011), and the diet alters the mineral content of the body tissue (Ireland and Marigomez, 1992; Ademolu et al., 2004) with potential consequences for their vulnerability to female flies.

The present study documents a high potential predation pressure and a positive relationship between external attack and internal utilization marks in subpopulations of $H$. pomatia in unfavourable environmental conditions. Previous studies documented that protection of $H$. pomatia subpopulations against vertebrate predators can contribute to an increase of population sizes (Sherley et al., 1998; Neuweger et al., 2001). In such conservation programmes, it is important to consider that external predators prefer larger individuals. Predators may vacate a feeding site, as soon as large individuals are exploited, and the snail population may recover relatively quickly after major predator species vacated the area (Mead, 1979). As $H$. pomatia has one of the highest legal protection statuses in Germany, priority needs to be given to the protection of suitable habitats.

Data availability. Data can be requested via the responsible author Claudia Tluste: claudia.fuessel@yahoo.de.

Author contributions. CT carried out the field work as well as the data processing and the writing of the paper. $\mathrm{KB}$ was responsible for statistical analyses in Sect. 2.4 as well as corrections within the paper. UB was responsible for corrections in between and provided advice. TN provided additional helpful information regarding shell marks.

Competing interests. The authors declare that they have no conflict of interest.
Acknowledgements. We thank the municipality of Cottbus for the permission to perform research in the "Sachsendorfer Wiesen" landscape protection area. Matthias Foellmer, Carolyn Trietsch, one anonymous referee and the subject editor contributed valuable comments to a previous version of this manuscript.

Review statement. This paper was edited by Matthias Foellmer and reviewed by Carolyn Trietsch and one anonymous referee.

\section{References}

Ademolu, K. O., Idowu, A. B., Mafiana, C. F., and Osinowo, O. A.: Performance, proximate and mineral analyses of African giant land snail (Archachatina marginata) fed different nitrogen sources, Afri. J. Biotechnol., 3, 412-417, https://doi.org/10.5897/AJB2004.000-2079, 2004.

Allen, J. A.: Avian and mammalian predators of terrestrial gastropods, in: Natural enemies of terrestrial molluscs, edited by: Barker, G. M., CABI Publishing, New Zealand, 11-25, 2004.

Anderson, M., Gorley, R., and Clarke, K.: PERMANOVA for PRIMER, user manual, Primer-E Ltd, Plymouth, United Kingdom, 2008.

Andreev, N.: Assessment of the status of wild populations of land snail (escargot) Helix pomatia L. in Moldova: the effect of exploitation, Biodivers. Conserv., 15, 2957-2970, https://doi.org/10.1007/s10531-005-3433-1, 2006.

Arimoro, F. O., Ikomi, R. B., and Iwegbue, C. M. A.: Water quality changes in relation to Diptera community patterns and diversity measured at an organic effluent impacted stream in the Niger Delta, Nigeria, Ecol. Indic., 7, 541-552, https://doi.org/10.1016/j.ecolind.2006.06.002, 2007.

Barker, G. M., Knutson, L., Vala, J.-C., Coupland, J. B., and Barnes, J. K.: Overview of the Biology of Marsh Flies (Diptera: Sciomyzidae), with special references to predators and parasitoids of terrestrial gastropods, in: Natural enemies of terrestrial molluscs, edited by: Barker, G. M, CABI Publishing, New Zealand, 159-226, 2004.

Bateman, M. A. and Morton, T. C.: The importance of ammonia in proteinaceous attractants for fruit flies (Family: Tephritidae), Aust. J. Agr. Res., 32, 883-903, https://doi.org/10.1071/AR9810883, 1981.

Baum, I. B., Willer, M. W., and Szmant, A. M.: Ecology of a corallivorous gastropod, Coralliophila abbreviata,on two scleractinian hosts, II, Feeding, respiration and growth, Mar. Biol., 142, 10931101, https://doi.org/10.1007/s00227-003-1053-4, 2003.

Beaver, O. P.: Egg laying studies on some British sciomyzid flies (Diptera: Sciomyzidae), Hydrobiologia, 43, 1-12, https://doi.org/10.1007/BF00014252, 1973.

Beaver, R. A.: Non-Equilibrium "Island" communities: Diptera breeding in dead snails, J. Anim. Ecol., 46, 783-798, 1977.

Bloszyk, J., Machnikowski, M., Napierala, A., Goldyn, B., Rybska, E., Stepczak, K., Szybiak, K., Konwerski, S., Leszczynska-Deja, K., Dylewska, M., Kalinowski, T., and Jankowiak, A.: Assessment of abundance and distribution of the Roman snail (Helix pomatia Linnaeus, 1758) in Kujawsko-Pomorskie voivodeship, Folia Malacologica, 18, 113-121 https://doi.org/10.2478/v10125010-0014-z, 2010. 
Bouchet, P., Falkner, G., and Seddon, M. B.: List of protected land and fresh water molluscs in the Bern Convention and European Habitats Directive: are they relevant to conservation?, Biol. Conserv., 90, 21-31, https://doi.org/10.1016/S0006-3207(99)000099, 1999.

Brodersen, J., Chimbari, M. J., and Madsen, H.: Laboratory experiments on snail-size selection by a snail predator, Sargochronis codringtoni (Pisces: Cichlidae), J. Mollus Stud., 68, 194-196, https://doi.org/10.1093/mollus/68.2.194, 2002.

Buck, M., Bergeron, M. D., and Marshall, S. A.: First New World record of Discomyza incurva (Fallén) from Southern Ontario, with a key to new world Discomyza Meigen (Diptera: Ephydridae), Journal of the Entomological Society of Ontario, 137, 111-115, available at: http://www.entsocont.ca/uploads/3/ 0/2/6/30266933/137_111_115.pdf (last access: 5 August 2020)m 2006.

Coupland, J. B. and Barker, G. M. (Eds.): Diptera as Predators and Parasitoids of Terrestrial Gastropods, with Emphasis on Phoridae, Calliphoridae, Sarcophagidae, Muscidae and Faniidae, in: Natural enemies of Terrestrial Molluscs, edited by: Barker, G. M, CABI Publishing, New Zealand, 85-158, 2004.

Davies, P. W. and Snow, D. W.: Territory and food of the Song Thrush, Brit. Birds, 58, 161-175, May 1965.

Digweed, S. C.: Selection of terrestrial gastropod prey by cychrine and pterostichine ground beetles (Coleoptera: Carabidae), Can. Entomol., 125, 463-472, https://doi.org/10.4039/Ent125463-3, 1993.

Drake, C. M.: British Ephydridae (Diptera), available at: https://www.diptera-in-beeld.nl/ Ref-KeyEphydridaeBritishkey-new(2006)-C.M.Drake.pdf (last access: 22 May 2020), 2006.

Duyck, P. F., Rousse, P., Ryckewaert, P., Fabre, F., and Quilici, S.: Influence of Adding Borax and Modifying $\mathrm{pH}$ on Effectiveness of Food Attractants for Melon Fly (Diptera: Tephritidae), J. Econ. Entomol., 97, 1137-1141, https://doi.org/10.1093/jee/97.3.1137, 2004.

Dwek, M. V., Ross, H. A., Streets, A. J., Brooks, S. A., Adam, E., Titcomb, A., Woodside, J. V., Schumacher, U., and Leathem, A. J.: Helix pomatia agglutinin lectin-binding oligosaccharides of aggressive breast cancer, Int. J. Cancer, 95, 79-85, 2001.

Elmslie, L. J.: Humic acid: a growth factor for Helix aspersa Müller (Gastropoda: Pulmonata), J. Mollus. Stud., 64, 400-401, https://doi.org/10.1093/mollus/64.3.400, 1998.

Epsky, N. D., Heath, R. R., Sivinski, J. M., Calkins, C. O., Baranowski, R. M., and Fritz, A. H.: Evaluation of protein bait formulations for the Caribbean fruit fly (Diptera: Tephritidae), Fla. Entomol., 76, 626-635, https://doi.org/10.2307/3495797, 1993.

Ferrar, P.: http://milichiidae.info/sites/milichiidae.info/files/Ferrar_ 1987_222.pdf (last access: 22 May 2020), 1987.

Gheoca, V.: Edible land snail Helix pomatia's exploitation in Central Romania-legislation, evolution, perspectives, Advances in Environment, Ecosystems and Sustainable Tourism, 144-149, 2013

Goodfriend, G. A.: Variation in land-snail shell form and size and its causes: a review, Syst. Biol., 35, 204-223, https://doi.org/10.1093/sysbio/35.2.204, 1986.

Goodhart, C. B.: Thrush predation on the snail Cepaea hortensis, JSTOR Collection, J. Anim. Ecol., 27, 47-57, https://doi.org/10.2307/2173, 1958.
Gruar, D., Peach, W., and Taylor, R.: Summer diet and body condition of Song Thrushes Turdus philomelos in stable and declining farmland populations, Ibis, 145, 637-649, https://doi.org/10.1046/j.1474-919X.2003.00202.x, 2003.

Grunewald, J.: The hydro-chemical and physical conditions of the environment of the immature stages of some species of the simulium (Edwardsellum) damnosum complex (Diptera), Tropenmed. Parasitol., 27, 438-454, 1976.

Hardouin, J.: Minilivestock: from gathering to controlled production, Biodivers. Conserv., 4, 220-232, https://doi.org/10.1007/BF00055969, 1995.

Heath, R. R., Epsky, N. D., Bloem, S., Bloem, K., Acajabon, F., Guzman, A., and Chambers, D.: pH Effect on the attractiveness of a corn hydrolysate to the Mediterranean fruit fly and several Anastrepha species (Diptera: Tephritidae), J. Econ. Entomol., 87, 1008-1013, https://doi.org/10.1093/jee/87.4.1008, 1994.

Hofer, A. and Waitzbauer, W.: Beitrag zur Entomofauna des Naturschutzgebietes Eichkogel bei Mödling (Niederösterreich) 1, Ausgewählte Diptera (Insecta) der Trockenrasen, Verhandlungen der Zoologisch-Botanischen Gesellschaft in Wien, 137, 130, 2000.

Ireland, M. P. and Marigomez, I.: The influence of dietary calcium on the tissue distribution of $\mathrm{Cu}, \mathrm{Zn}, \mathrm{Mg}$ and $\mathrm{P}$ and histological changes in the digestive gland cells of the snail Achatina fulica Bowdichm, J. Mollus. Stud., 58, 157-168, https://doi.org/10.1093/mollus/58.2.157, 1992.

Knutson, L. and Vala, J.-C.: An evolutionary scenario of Sciomyzidae and Phaeomyiidae (Diptera), Ann. Soc. Entomol. Fr., 38, 145-162, 2002.

Kofler, A. and Mildner, P.: Third supplement of the mollusk fauna of East Tyrol (Mollusca: Gastropoda, Bivalvia), Berichte des naturwissenschaftlichen-medizinischen Verein Innsbruck, 91, 129-155, available at:https://www.zobodat.at/pdf/BERI_91_ 0129-0155.pdf (last access: 30 July 2020), 2004.

Krištin, A.: Trophische Beziehung zwischen Singvögeln und Wirbellosen im Eichen-Buchenwald zur Brutzeit, Der ornithologische Beobachter, 89, 157-169, 1992.

Larochelle, A.: The food of Carabid beetles (Coleoptera: Carabidae, Including Cicindelinae), Fabreries Supplements, 5, 1-132, 1990

Legendre, P. and Anderson, M. J.: Distance-based redundancy analysis: testing multispecies responses in multifactorial ecological experiments, Ecol. Monogr., 69, 1-24, https://doi.org/10.1890/00129615(1999)069[0001:DBRATM]2.0.CO;2, 1999.

Liew, T. S. and Schilthuizen, M.: Association between shell morphology of micro-land snails (genus Plectostoma) and their predator's predatory behaviour, PeerJ, 2, e329, https://doi.org/10.7717/peerj.329, 2014.

Ligaszewski, M., Pol, P., Radkowska, I., Sorówka, K., and Łysak, A.: Results of research on the active species protection of the Roman snail (Helix pomatia, Linnaeus, 1758) using farmed snails in the second year of life, First season of the study, Ann. Anim. Sci., 14, 377-389, https://doi.org/10.2478/aoas-2013-0068, 2014.

Ligaszewski, M., Pol, P., and Radkowska, I.: Observations on Growth Rates and Maturity in an Introduced Population of the Roman Snail (Helix pomatia Linnaeus, 1758) at a Semi-Natural Site with no Natural Population, Malacologia, 59, 341-347, https://doi.org/10.4002/040.059.0212, 2016. 
Lind, H.: Homing to Hibernating Sites in Helix pomatia Involving Detailed Long-term Memory, Ethology, 81, 221-234, https://doi.org/10.1111/j.1439-0310.1989.tb00768.x, 1989.

McArdle, B. H. and Anderson, M. J.: Fitting multivariate models to community data: A comment on distance-based redundancy analysis, Ecology, 82, 290-297, https://doi.org/10.1890/00129658(2001)082[0290:FMMTCD]2.0.CO;2, 2001.

Mead, A. R.: The Giant African Snail: A Problem in Economic Malacology, University of Chicago Press, Chicago, United States, 257 pp., ASIN: B00116T16Q, 1961.

Mead, A. R.: Economic malacology with particular reference to Achatina fulica, in: The Pulmonates, Vol 2B, edited by: Fretter, V. and Peake, J., Academic Press, New York, United States, 1979.

Mensink, P. J. and Henry, H. A. L.: Rain events influence shortterm feeding preferences in the snail Cepaea nemoralis, J. Mollus. Stud., 27, 241-247, https://doi.org/10.1093/mollus/eyr011, 2011.

Millar, A. J. and Waite, S.: Molluscs in coppice woodland, J. Conchol., 36, 25-48, 1999.

Millar, A. J. and Waite, S.: Patterns of shell damage among snails from a coppice woodland in Sussex, England, J. Conchol, 38, 421-440, 2004.

NABU (Naturschutzbund Deutschland): available at: https://brandenburg.nabu.de/tiere-und-pflanzen/sonstige-arten/ 24240.html (last access: 22 May 2020), 2019.

Němec, T. and Horsák, M.: Specific damage recognised on land snail shells as a tool for studying predation intensity: differences related to habitat and predator types, Contrib. Zool., 88, 277-296, https://doi.org/10.1163/18759866-20191402, 2019.

Neuweger, D., White, P., and Ponder, W. F.: Land snails from Norfolk Island sites, Rec. Aust. Mus., 28, 115-122, https://doi.org/10.3853/j.0812-7387.27.2001.1346, 2001.

Nicolai, A. and Ansart, A.: Conservation at a slow pace: terrestrial gastropods facing fast-changing climate, Conserv. Physiol., 5, 117 https://doi.org/10.1093/conphys/cox007, 2017.

Oosterhoff, L. M.: Variation in growth rate as an ecological factor in the landsnail Cepaea nemoralis (L.), E. J. Brill, Leiden, Netherlands, 132 pp., 1977.

Rosin, Z. M., Olborska, P., Surmacki, A., and Tryjanowski, P.: Differences in predatory pressure on terrestrial snails by birds and mammals, J. Bioscience, 36, 691-699, https://doi.org/10.1007/s12038-011-9077-2, 2011.

Seike, K., Sassa, S., Shirai, K., and Kubota, K.: Fate of benthic invertebrates during seabed liquefaction: Quantitative comparison of living organism body density with liquefied substrate density, Estuar. Coast Shelf S., 223, 1-5, https://doi.org/10.1016/j.ecss.2019.04.025, 2019.

Sepúlveda, R. D., Jara, C. G., and Gallardo, C. S.: Morphological analysis of two sympatric ecotypes and predatorinduced phenotypic plasticity in Acanthina monodon (Gastropoda: Muricidae), J. Mollus. Stud., 78, 173-178, https://doi.org/10.1093/mollus/eyr058, 2012.
Sequy, E.: Faune de France, Dipteres (Bracelyceres): http://faunedefrance.org/biblotheque/docs/E.SEGUY(FdeFr28) Dipt.Brachyceres.pdf (last access: 26 July 2018), 1934.

Sherley, G. H., Stringer, I. A. N., Parrish, G. R., and Flux, I.: Demography of two landsnail populations (Placostylus ambagiosus, Pulmonata: Bulimulidae) in relation to predator control in the far north of New Zealand, Biol. Conserv., 84, 83-88, https://doi.org/10.1016/S0006-3207(97)00086-4, 1998.

South, A.: Terrestrial slugs: Biology, ecology and control, Springer Science+Business Media, Dordrecht, Netherlands, 196-198, 1992.

Steward, W. J. and McHenry, M. J.: Sensing the strike of a predator fish depends on the specific gravity of a prey fish, J. Exp. Biol., 213, 3769-3777, https://doi.org/10.1242/jeb.046946, 2010.

Symondson, W. O. C.: Coleoptera (Carabidae, Staphylinidae, Lampyridae, Dirilidae and Silphidae) as predators of Terrestrial Gastropods, in: Natural Enemies of Terrestrial Molluscs, edited by: Barker, G. M., CABI International, New Zealand, 37-84, ISBN 0851993192, 2004.

Uutala, A. J.: Paleolimnological Assessment Of The Effects Of Lake Acidification On Chironomidae (Diptera) Assemblages In The Adirondack Region Of New York, available at: https: //elibrary.ru/item.asp?id=7550704 (last access: 23 May 2020), 1987.

Vermeij, G. J.: A natural history of shells, Vol. 15, Princeton University Press, Princeton, New Jersey, United States, 1995.

von Bergenstamm, J.: Über die Metarmorphose von Discomyza incurva Fall, Zool.-Bot. Ges. Österreich Austria, available at: https://www.zobodat.at/ (last access: 22 May 2020), 1864.

Welch, J. M. and Pollard, E.: The exploitation of helix pomatia L., Biol. Conserv., 8, 155-160, https://doi.org/10.1016/00063207(75)90040-3, 1975.

Wheater, C. P.: Observations on the food of Staphylinus olens Müller (Col., Staphylinidae), Entomologist's Monthly Magazine, 123, 116, 1987.

Wollmann, E.: Botanische Studien zu den Sachsendorfer Wiesen, Natur und Landschaft in der Niederlausitz, 22, edited by: Striegler, R., Heym, W.-D., and Schneider, B., Cottbus, Germany, 99, 2002.

Zach, R.: Shell dropping: Decision-making and optimal foraging in Northwestern Crows, Behaviour, 68, 106-117, https://doi.org/10.1163/156853979X00269, 1978.

Zatwarnicki, T. and Mathis, W. N.: A revision of the Palearctic species of the shore-fly genus Discomyza Meigen (Diptera: Ephydridae), Insect. Syst. Evol., 38, 241-266, https://doi.org/10.1163/187631207788754448, 2007. 